\title{
An approach towards Inclusion for Food Grain Storage Guidelines and Norms in URDPFI Guidelines
}

\author{
Ar. Sayan Mukherjee, Shubham Yadav, Ar. Sonam Vaidya \\ Dept. of Urban Planning, University Teaching Department, Chhattisgarh Swami Vivekanand Technical \\ University, Bhilai - 491007 (C.G.), India \\ Corresponding author Email: Sonamvd31@gmail.com
}

\begin{abstract}
Agricultural Development is an integral part of overall economic development of India. Agriculture produces, supply, distribution and allied services contributed to nearly $57 \%$ of our country's national income. Since independence nearly $60 \%$ of labour force was engaged in agricultural profession directly or indirectly. During the period of 1950-51, the food grain production in India was 51 million metric tonne and it roses to staggering $580 \%$ to 296 million metric tonne in 2019 . The food grains from across country are collected by Government of India and state governments and stored in godowns and warehouses of Food Corporation of India (FCl), Central Warehousing Corporations (CWC), State warehousing Corporation (SWC) and Private Warehouses. Majority of these godowns and warehouses now falls under urban or sub-urban areas due to expansion of cities. The storage, supply and distribution of food grains in urban areas need proper rules and guidelines in URDPFI guidelines for future storages.
\end{abstract}

Keywords: Agriculture, Food Grain, Storage, Supply chain, Distribution, URDPFI

\section{Introduction}

India, an agrarian country majorly employs around $60 \%$ populations in agriculture and allied services, agriculture sector is vital for the food and nutritional security of the nation ${ }^{1}$. The sector is the principal source of livelihood for more than $60 \%$ of the population even though the contribution of agricultural sector to the Gross Domestic Product (GDP) is only $17 \%$. Geographically, India shares $2.3 \%$ of world's total land area but it has to ensure the food security of its population which is about $17.5 \%$ of world population.

This leads to excessive pressure on land and fragmentation of land holdings. Against the scenery of the expanding populace's requests for food grains, debasing common asset base, arising worries of environmental change and different difficulties, the Department of Agriculture and Cooperation (DAC) has zeroed in on preparing higher interest in agribusiness, connecting yield holes that exist over the states/locales, opportune and sufficient gracefully of value inputs, and offering satisfactory help administrations to the ranchers to make horticulture a gainful job on a practical premise.

Expanding horticultural creation with restricted regular assets in a maintainable way for guaranteeing food and nourishing security and turning out revenue security to ranchers are the significant difficulties before the Government.

According to the Advance Estimates (AE) of Central Statistical Organization for the year 2010-11, the agrarian area contributed about 14.2 percent to the GDP, at 2004-05 costs. There has been a consistent decrease in the portion of agribusiness in the GDP from 17.4 percent in 2006-07 to 14.2 percent in 2010-11 according to Advance Estimates at 2004-05 costs. Falling portion of farming in GDP is a normal result in a quickly developing and basically evolving economy. India is continuously facing pressure on the demand side due to steady population growth, limited land availability, and several other production deterrents, which might also appear as obstacles for the supply of food grains. Indian government policies and 
planning has always given considerable importance to production of food grains due to which India has been achieving the continued growth despite many constraints. During the last decade (2000-01 to 2010-11), the areas under cereals, pulses, and oil seeds have increased by about5.7,6.0, and 4.0 million hectares, respectively, and the area under coarse cereals has declined by 2.6 million hectares. The area under wheat cultivation has accelerated significantly in comparison to other cereals and millets.

However, a moderate deceleration in total grain cultivated area in comparison to pulses cultivated area was witnessed during the years of 2005 to 2011. The highest food grain production of 259.32 million tonnes was recorded in 2011-12. Out of the total food grains production, cereals accounted for 242.23 million tonnes and pulses 17.09 million tonnes. Production of rice and wheat was recorded at105.3 and 94.9 million tonnes, respectively. It was estimated that the agriculture sector in India is likely to grow by $5.2-5.7 \%$ in $2013-14$. India is one of the largest producers of cereal as well as the largest exporter of cereal products worldwide. India's export of cereals during 2013-14 stood at Rs.63452.09 crores. Rice (including basmati and non-basmati) occupies the most sizable share in India's total cereals export with $64.40 \%$ during this period [2].

\section{Food Grain production and storage in India}

The food grain production in India was 51 million metric tonne in 1950-51and it rose to staggering 6 times to 296 million metric tonne in 2019. The population of India was 36 crore in 1950-51 and it increased to 130 crore in 2019. During this period of 70 years the annual budget increased many fold from 290 crore to 42500 crore in 2019. However, the storage of food grains didn't see much of capacity building with just 1.0 million metric tonne in 1950-51 to 43 million metric tonne in 2017. Every year Government of India is increasing its budget on agriculture, allied services and storage facilities across the country. (Fig. 1)

\begin{tabular}{|c|c|c|c|c|c|c|c|c|c|c|c|}
\hline Indicators & $1950-51$ & $1960-61$ & 1990.91 & $2000-01$ & $2010-11$ & $2011-12$ & $2012 \cdot 13$ & $2013-14$ & $2014-15$ & $2015 \cdot 16$ & $2016-17$ \\
\hline Population & 361 & 440 & 846 & 1028 & 1186 & 1220 & 1235 & 1251 & 1267 & 1283 & 1299 \\
\hline Birth Rate (per 1000) & 399 & 4.1. & 29.5 & 25.4 & 21.8 & 21.6 & 21.4 & 21.0 & 20.8 & 20.4 & 20.1 \\
\hline $\begin{array}{l}\text { Per Capta Net } \\
\text { Nationat Income (FS) }\end{array}$ & 7513 & 9482 & 15996 & 22491 & 39270 & 63462 & 65538 & 68572 & 72805 & 77826 & 82229 \\
\hline $\begin{array}{l}\text { Agriculture and allied } \\
\text { sector budget (RS. Cr) }\end{array}$ & 290 & 549 & 1531 & 2969 & 18649 & 21530 & 25350 & 27049 & 28198 & 21828 & 25700 \\
\hline $\begin{array}{l}\text { Food Grains (milition } \\
\text { tonnes) }\end{array}$ & 50.8 & 82.0 & 176.4 & 196.8 & 244.5 & 259.3 & 257.1 & 265.0 & 2520 & 251.6 & 275.1 \\
\hline $\begin{array}{l}\text { Food drain Per Capita } \\
\text { Per Day (Gms) }\end{array}$ & 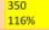 & 年 ${ }_{133 \%}$ & 年4 ${ }_{15 \%}$ & $\begin{array}{l}4758 \mathrm{~K} \\
{ }_{158}\end{array}$ & $\begin{array}{l}492 \\
1645 \\
{ }_{164}\end{array}$ & $\begin{array}{l}510 \\
170 \%\end{array}$ & $\begin{array}{l}480 \\
160 \% \\
\end{array}$ & $\begin{array}{l}485 \\
161 \% \\
{ }_{161}\end{array}$ & $\begin{array}{l}525 \\
175 \%\end{array}$ & $\begin{array}{l}560 \\
186 \%\end{array}$ & $\begin{array}{l}579 \\
199 x\end{array}$ \\
\hline $\begin{array}{l}\text { Aericicultural tabourers } \\
\text { (crores) }\end{array}$ & 28.1 & 24.0 & 40.3 & 45.6 & 49.8 & 55.2 & 56.5 & 58.2 & 624 & 643 & 66.8 \\
\hline Trade Export (Crore) & 606 & 642 & 32553 & 203571 & 1136964 & 1465959 & 1634319 & 1905011 & 1896348 & 1716378 & 1849429 \\
\hline Trade Import (corore) & 608 & ${ }_{1122}$ & ${ }^{43198}$ & 230873 & 1683367 & ${ }^{23345463}$ & 2669162 & 2715434 & 2737087 & 2490298 & 2577666 \\
\hline $\begin{array}{l}\text { Food Grain storage } \\
\text { Capacity (MMT) }\end{array}$ & 12 & 25 & 8.5 & 13.8 & 24.742 & 27.739 & 31.163 & 29.808 & 34922 & 37.484 & 41.293 \\
\hline
\end{tabular}

Fig 1, Comparison of agricultural figures with various social and economic indicators [3]

Source: Pocketbook of Agricultural statistics -2017, Government of India, Ministry of Agriculture \& Farmers Welfare, Department of Agriculture, Cooperation \& Farmers Welfare, Directorate of Economics \& Statistics, New Delhi.

\subsection{Storage facilities of food grains in India}

Year wise figures of food grain storage with Food Corporation of India is given in Table 1 [4]

Table 1

\begin{tabular}{|l|l|l|l|}
\hline \multirow{2}{*}{$\begin{array}{l}\text { Time } \\
\text { Period }\end{array}$} & \multicolumn{2}{|l|}{ Storage Capacity } & \multicolumn{1}{l|}{ Total } \\
\cline { 2 - 4 } & FCI & Other & \\
\hline $01-04-2011$ & 316.10 & 291.32 & 607.42 \\
\hline $01-04-2012$ & 336.04 & 341.35 & 677.39 \\
\hline $01-04-2013$ & 377.35 & 354.28 & 731.63 \\
\hline $01-04-2014$ & 368.90 & 379.18 & 748.08 \\
\hline $01-04-2015$ & 356.63 & 352.59 & 709.22 \\
\hline $01-04-2016$ & 357.89 & 456.95 & 814.84 \\
\hline $01-04-2017$ & 352.71 & 420.22 & 772.93 \\
\hline $01-04-2018$ & 362.50 & 480.53 & 843.03 \\
\hline $01-04-2019$ & 388.65 & 467.03 & 855.68 \\
\hline $01-04-2020$ & 412.03 & 343.91 & 755.94 \\
\hline
\end{tabular}

Source: https://fci.gov.in/storages

\subsection{Supply and Distribution of Food Grains}


The demand of the food grain is continuously increasing because of increasing the population of the world. To satisfy the increased demand of this population there is a need of more production, more procurement and less wastage of food grains during transit and storage. The food corporation of India (FCI) is the central nodal agency which responsible for handling procurement, storage, movement, transportation and distribution activities of food grains throughout the country. In this work we consider the special case of transportation and distribution of food grains of PDS which is the largest retail system of its type in the world and carried out by FCI.

One of the objectives of FCIs is to provide the food grains to needy peoples of the society at reasonable prices. Transportation cost is the major part of this process and to reduce this cost, it needs the effective and efficient movement of food grains from the producing states to consuming states. The movement of food grains is taking place between the producing states and consuming states.

Currently, $45 \%$ food grains are getting wasted from the post-harvest to distribution stage due to the lack of proper handling, transportation and infrastructure. To reduce this storage and transit losses and to modernize the system of handling, storage and transportation of food grains the Government of India (GOI) has formulated National Policy on Handling, Storage and Transportation of food grains.

The current scenario of food grain transportation in India is having some shortfalls and it requires huge amount of cost for transportation. There is on an average 2 million bags (50 kg per bag) of food grains are transported daily by rail, road, inland waterways etc. from producing states to consuming states which covers the average $1500 \mathbf{~ k m}$ distance

(http://www.fci.gov.in/movements/view/5) . This movement incurred annual cost of 47.2737 billion INR (CAG, 2013). The stock of food grains in the central pool as on $1^{\text {st }}$ June 2012 is $\mathbf{6 6 7 . 8 9}$ LMT excluding the Decentralize procurement (DCP) states procurement against the total of $\mathbf{4 9 1 . 8 6}$ LMT FCIs capacity including the state warehousing corporation (SWC) and central warehousing corporation (CWC) capacities (CAG, 2013). This wide gap shows the needs of more storage capacity to cope with the procurement of food grains. In addition to this, key issues of FCIs are shortages of labours, optimal inventory level and handling cost, wastages in transit and warehouses, leakages PDS, carry over charges and demurrage charges of railway rakes etc ${ }^{5}$.

\subsection{Mode of Transportation}

Movement of food grains is undertaken by Rail, Road and Waterways. Around $85 \%$ of stocks are moved by rail to different parts of the country. Inter-State movement by road is mainly undertaken in those parts of the country which are not connected by rail. A small quantity is also moved by ocean vessels to Lakshadweep and A\&N Islands as well as through coastal shipping and riverine movement to Kerala/Agartala (Tripura).

FCI has 98 own Rail sidings, where food grain rakes are placed directly at FCI depots. Other than that, food grain stocks are transported 'to and fro' from the nearest railheads of Indian Railways.

FCI has been able to ensure availability of sufficient food grain in all States by proper planning. About a decade back, nearly $\mathbf{9 0 \%}$ of stocks were moved Ex-North mainly from Punjab \& Haryana, which has now come down to $\mathbf{7 2 \%}$ due to increase in procurement of rice in Andhra Pradesh, Chhattisgarh, Odisha\& West Bengal and wheat in Madhya Pradesh, Uttar Pradesh and Rajasthan [6].

Approximately 36 crore two axle trucks were engaged in movement and transportation of food grains across the 
country in the year 2019-20 with an average of $\mathbf{3}$ crore two axle truck engaged in mobilization every month.

\section{Need of the study}

The storage facilities of food grains are carried out by Food Corporation of India (FCI), Central Warehousing Corporations (CWC), State warehousing Corporation (SWC) and Private Warehouses. Majority of these godowns and warehouses now falls under urban or sub-urban areas due to expansion of cities. The storage, supply and distribution of food grains in urban areas need proper rules and guidelines in URDPFI guidelines for future storages.

\subsection{Data Analysis and Interpretation}

Current storage facility of FCI godowns in country is 41.30 million metric tonne. With the growing demand of food industry in our country, the target storage capacity has to be increased upto 250 million metric tonnes. With the aggressive expansion of urban areas all over the country, the storage/ warehouse capacity has to be increased manifold. The URDPFI guidelines for 'Space Norms' (8.2.11.3. Space Norms) mentioned by Central Warehousing Corporation (CWC) is $1054 \mathrm{Kg} . /$ Sq. m. ${ }^{7}$

With the future plan for increasing the storage facilities across the country, the mobility of commercial vehicles for supply and transportation will also increase which in turn will affect the transportation network in urban and suburban areas.

\subsection{Limitation of the study}

All the data presented in this study are secondary data, the quantity of production and storage only represents food grain, pulses and oilseed, it does not include the production and storage of perishable items like vegetables, fruits and live stocks.

\section{Conclusion}

The farmers population in India largely includes small and marginal farmers, there are $67 \%$ marginal farmers and $18 \%$ small farmers, these farmers due to limited land cannot afford holding of commodity in improved storage structures. Indian economy largely depends on agriculture sector, it is ironic that the India's position in the world is as a major producer of agricultural food like Rice, wheat, Pulses etc, still the country is facing food scarcity. The storage capacity available with FCI is 41.30.52 Million ton, which was very limited as compared to India's overall food grain, oilseed and pulses production. Storage is an important link in the entire procurement and distribution system of food grains, produced seasonally but consumed all the year round. Therefore, storage facilities in India need to be strengthened by supplying them with the much-needed scientific storage. It is not feasible to formulate individual storage infrastructure for near about $85 \%$ of small and marginal farmers. This can be achieved through supplying storage capacity to farmer groups.

The current surplus food grain production can be utilized by enhancing storage facilities of FCI, CWC and SWC. This enhancement can be accelerated by inclusion of rules and guidelines of food grain storage in URDPFI guidelines along with existing transportation, infrastructure planning and spacing norms.

The inclusion of rules and guidelines for food grain storage in URDPFI guidelines is required with respect to the following:

i. With the current rate of increase in food grain production, the covered plinth area at various storage facilities have to be increased by 3 times, separate guidelines for food grain storage facilities in urban area are to be implemented.

ii. The transportation and supply of food grains in urban areas were staggering 3 crore two axle truck engaged in mobilization every month last year, considering future increase 
in traffic movement, additional transportation guidelines are required.

iii. Railway carries $\mathbf{8 5 \%}$ of the food grain across the country, through Public-Private-Partnership (PPP) business models, development of food grain storage silos and processing centers with commercial complexes at less-frequently used passenger halt stations can be

\section{References}

1. Annual Report 2010-2011, Department of Agriculture and Cooperation, Ministry of Agriculture, Government of India, March 2011.

2. Khatkar B.S., Chaudhary N. and Dangi P. (2016); Production and Consumption of Grains: India.

3. Pocketbook of Agricultural statistics 2017, Government of India, Ministry of Agriculture \& Farmers Welfare, developed. Rules and regulations with respect to food grain management, environmental impact, regional GDP, supply and distribution in URDPFI guidelines are needed for development of these urban infrastructures.

\section{Conflict of Interest}

The authors declare no conflict of interest.

4. Department of Agriculture, Cooperation \& Farmers Welfare, Directorate of Economics \& Statistics, New Delhi. https://fci.gov.in/storages

5. D.G. Mogale et al. / IFAC-Papers OnLine 49-12 (2016)1767-1772; Two stage food grain supply chain network transportation - Allocation model.

https://fci.gov.in/movements.php

6. URDPFI Guidelines WL-2014 